\title{
26 INFORMATION SYSTEMS AND THE SERVICE ECONOMY: A Multidimensional Perspective
}

\author{
Steven Alter \\ University of San Francisco, U.S.A. \\ Uri Gal \\ University of Aarhus, Denmark \\ David Lipien \\ IBM Corporation \\ Kalle Lyytinen \\ Case Western Reserve University, U.S.A. \\ Nancy Russo \\ Northern Illinois University, U.S.A.
}

\section{INTRODUCTION}

This panel will examine the impact of the growth of the service economy on organizations and information systems from four perspectives: (1) internal changes in organizations, both service providers and service clients, in terms of their structures, processes, and competencies; (2) redefinition of interorganizational relationships and redrawing of organizational boundaries and identities; (3) the role of IS in enabling these new collaborative relationships; and (4) the possibility of designing better applications to enhance organizations' capacity to engage in service exchanges.

Please use the following format when citing this chapter:

Alter, S., Gal, U., Lipien, D., Lyytinen, K., and Russo, N. L., 2008, in IFIP International Federation for Information Processing, Volume 267, Information Technology in the Service Economy: Challenges and Possibilities for the $21^{\text {st }}$ Century, eds. Barrett, M., Davidson, E., Middleton, C., and DeGross, J. (Boston: Springer), pp. 349-352. 


\section{PANEL DESCRIPTION}

We live in a post-manufacturing world. Throughout most of the industrial era, the output of manufacturing has been product. The key to success was the ability of an organization to make more products cheaper than most other producers. In recent decades, many organizations are facing increased competition from producers that can make products as well as or better than they can and for lower prices. To stay competitive, many organizations have to redefine their business to emphasize the services they offer rather than the product they manufacture. This implies using the products they make for their customers as a platform to integrate a comprehensive set of services and processes to meet their clients' needs. These services represent a relationship between the provider and the client, comprised not just of technology but of people as well (Maglio et al. 2006). Today, nearly 80 percent of our economic activity consists of service jobs that comprise the service economy (Chesbrough and Spohrer 2006).

To become service oriented and increase service productivity, many organizations have reorganized their basic structure, created new organizational roles, and retrained their employees (or hired new ones). Additionally, they have reengineered their business processes, redefined their core competencies, and reconfigured their supply chains and relationships with key customers and suppliers. Indeed, changes to the providercustomer relationship are central to the emergence of the service economy. When products were the main focus of the exchange, they constituted a concrete mechanism, or boundary object, that facilitated interorganizational communication and reduced uncertainties. As products, their embedded technical standards, and their functionalities became well understood, suppliers did not need to understand the customers' business to become an exchange partner. Similarly, customers did not have to understand their providers' previous experiences and expertise as these were reflected in tangible products (Chesbrough and Spohrer 2006). The delivery of services is qualitatively different in that it lacks a concrete artifact that mediates the relationship. It involves, instead, an ongoing exchange of intangible assets between a provider and an adopter in which both parties play an active part. In this exchange, each party needs the other's knowledge in negotiating its involvement and role.

The provider lacks the contextual knowledge of the customer's business, and how the customer is going to leverage the offering to compete more effectively....The customer lacks the knowledge of the full capabilities of the provider's technologies, and the experience of the provider from other transactions in assessing what will work best (Chesbrough and Spohrer 2006, p. 37).

Service exchanges, therefore, require a closer and more comprehensive familiarity between the involved parties and are often built around long-term relationships that last over the life time of an enterprise.

Successful organizations are able to integrate interorganizational and intra-organizational processes and configure them according to changing client expectations (Zhao et al. 2007). However, creating the information systems to support these processes is no simple matter. Traditional design and development tools were not constructed to model such complex systems, nor do we have standard theory or methods available for formal representation or evaluation of these systems (Maglio et al. 2006). 
This raises a number of important issues that we wish to address in this panel.

Nancy Russo will open the panel with examples of new types of collaborative relationships between service providers and customers. She will highlight some of the main challenges organizations have faced when adjusting to these relationships and discuss how organizations have structured themselves internally to respond to these new conditions.

Kalle Lyytinen will address the following question that arises from the previous discussion: Do these collaborative relationships imply recharting organizational boundaries? If so, are there implications for the way organizations represent and define themselves, their goals, and their mission? Are there implications for organizational identities?

David Lipien will discuss the role of information systems in enabling these new collaborative relationships and examine their capacity to support broader and more comprehensive interorganizational interactions.

Steven Alter will inquire whether we can design better applications to enhance an organization's capacity to engage in service exchanges. Steve is the developer of the work system method, which has been proposed as a solution to the problem of how to model service systems.

Uri Gal will serve as the panel moderator.

\section{References}

Chesbrough, H., and Spohrer, J. 2006. "A Research Manifesto for Services Science," Communications of the ACM (49:7), pp. 35-40.

Maglio. P. P., Srinivasan, S., Kreulen, J. T., and Spohrer, J. 2006. "Service Systems, Service Scientists, SSME, and Innovation," Communications of the ACM (49:7), pp. 81-85.

Zhao, J. L. Tanniru, M. , and Zhang, L-J. 2007. "Services Computing as the Foundation of Enterprise Agility: Overview of Recent Advances and Introduction to the Special Issue," Information Systems Frontiers (9:1), pp. 1-8.

\section{About the Panelists}

Steven Alter is a professor of Information Systems at the University of San Francisco. He received a Ph.D. from MIT, taught at the University of Southern California, and was vice president of the manufacturing software firm Consilium before joining USF. His research for over a decade has concerned developing systems analysis concepts and methods that can be used by typical business professionals and can support communication with IT professionals. His latest book, The Work System Method: Connecting People, Processes, and IT for Business Results, is a distillation and significant extension of ideas in four editions $(1992,1996,1999,2002)$ of his information system textbook. His articles have been published in Harvard Business Review, Sloan Management Review, MIS Quarterly, IBM Systems Journal, Communications of the Association for Information Systems, and other journals and conference proceedings. Steve can be reached at stevenalter@comcast.net.

Uri Gal is an assistant professor of Information Systems at the Aarhus School of Business at the University of Aarhus. He holds a Ph.D. in Information Systems from Case Western Reserve University and an M.Sc. degree in Organizational Psychology from the London School of Economics and Political Science. His research takes a social view of organizational processes in the context of the implementation and use of information systems. He is particularly interested in the relationships between people and technology in organizations, and the changes in the nature of 
work practices, organizational identities, and interactions associated with the introduction of new information technologies. Uri can be reached by e-mail at urig@asb.dk.

David Lipien is a Senior Managing Consultant with IBM's Global Business Services Financial Services Insurance practice. He has over 10 years of IT systems development and leadership experience. He has expertise in all phases of the project life cycle and experience in numerous roles, including delivery executive, project manager, senior business analyst, and programmer. His specialties include Internet-based technologies, wireless, and object-based project methodologies. David is a PMI Certified Project Management Professional and holds a Bachelor of Science in Operations Management and Information Systems from Northern Illinois University and a Master of Business Administration from the University of Notre Dame. He has also completed an Executive Management Program at the Harvard Business School, and has published articles on the topic of enterprise software release management in IBM's international technical resource website, developerworks.com. David can be reached at lipien@us.ibm.com.

Kalle Lyytinen is the Iris S. Wolstein Professor at Case Western Reserve University, and adjunct professor at University of Jyväskylä, Finland. He serves currently on the editorial boards of several leading IS journals including Journal of AIS (currently as editor-in-chief), Journal of Strategic Information Systems, Information \& Organization, Requirements Engineering Journal, Information Systems Journal, Scandinavian Journal of Information Systems, and Information Technology and People, among others. He is an AIS fellow (2004), the former chairperson of IFIP 8.2 , and a founding member of SIGSAND. He has published over 150 scientific articles and conference papers and edited or written 10 books on topics related to nature of the IS discipline, system design, method engineering, organizational implementation, risk assessment, computer supported cooperative work, standardization, and ubiquitous computing. He is currently involved in research projects that looks at the IT induced radical innovation in software development, IT innovations in architecture, engineering, and the construction industry, design and use of ubiquitous applications, and the adoption of broadband wireless services in the U.K., South Korea, and the United States. Kalle can be reached atkalle@po.cwru.edu.

Nancy L. Russo is the Pavlović Professor of Information Systems at the Northern Illinois University's College of Business, and Partnership Director at Slobomir P University in the Republic of Srpska, Bosnia. She received her Ph.D. in Management Information Systems from Georgia State University. In addition to studies of the use and customization of system development methods, her research has addressed IT innovation, research methods, and IS education issues. Her work has appeared in Information Systems Journal, European Journal of Information Systems, Information Technology \& People, and Communications of the ACM. Nancy serves as vice chair of the IFIP WG 8.2 (Information Systems and Organizations). She can be reached at nrusso@niu.edu. 